Journal of Research in Nanoscience and Nanotechnology

\title{
Synthesis of Ag/ZnO Photocatalysts for the Photodegradation of Methyl Orange Dye
}

\author{
Elisa Rasouli ${ }^{1,2 *}$, Abdul Halim Abdullah ${ }^{1,3}$, Ernee Noryana Muhamad ${ }^{1}$, Pooneh Kia ${ }^{4}$ \\ Department of Chemistry, Faculty of Science, University Putra Malaysia, 43400, Serdang, \\ Selangor, Malaysia ${ }^{1}$ \\ Nanotechnology \& Catalysis Research Centre, Institute of Postgraduate Studies, University of \\ Malaya, 50603, Kuala Lumpur, Malaysia ${ }^{2}$ \\ Materials Synthesis and Characterization Laboratory, Institute of Advanced Technology, University Putra \\ Malaysia, 43400, Serdang, Selangor, Malaysia ${ }^{3}$ \\ Institute of Bioscience, University Putra Malaysia, Serdang 4300, Selangor, Malaysia ${ }^{4}$ \\ * Correspondence: elisa.rasouli@gmail.com,; Tel.: 00603-8946 6777 \\ https://doi.org/10.37934/jirnn.2.1.6169
}

\section{ABSTRACT}

$\mathrm{ZnO}$ and a series of $\mathrm{Ag} / \mathrm{ZnO}$ photocatalysts were prepared by a precipitation- irradiation method and their photocatalytic performance in photodegradation of methyl orange dye was evaluated. The physicochemical properties of the catalysts were characterized by various characterization techniques. The photocatalysts have a hexagonal phase and were highly agglomerated. TEM images showed a change in morphology of $\mathrm{ZnO}$ from rod to nearly spherical with the addition of $\mathrm{Ag}$. $\mathrm{Ag} / \mathrm{ZnO}$ catalysts exhibited better photocatalytic activity in the degradation of methyl orange compared to pure $\mathrm{ZnO}$. Ag/ZnO contains $2 \%$ silver shows the best performance as photocatalyst.

Keywords:

Dye; Methyl Orange; Precipitation-

irradiation method; Photocatalysis.

Received: 29 March 2021

Revised: 10 April 2021

Accepted: 20 April 2021

Published: 12 May 2021

\section{Introduction}

Water pollution, an important environmental issue, requires serious attention as it affects aquatic life and public health. It occurs when harmful organic and inorganic pollutants are discharged into open waters without proper treatment. Among these pollutants, dye has been a focus of many studies as it is widely used in many industries such as textile, food, and leather. Approximately $15 \%$ of the total world production of dyes is lost during the manufacturing process and released into the environment through textile effluents [1]. 
Dyes, once discharged, reduce the aesthetic value of water as they are extremely visible even in very small quantities. Furthermore, a majority of the dyes used in industry are toxic and carcinogenic and must be properly treated prior to discharge. Various methods including fenton and photo-fenton [1-4], ozonation [4] biodegradation [5,6], photocatalytic degradation [7,8], and adsorption are used in removing dyes from wastewater. Removal of dyes by adsorption is widely studied and has been critically reviewed.

Except for photocatalytic degradation, the advantages and disadvantages of these removal methods have also been compared $[9,10]$. Semiconductor photocatalysis currently receives increased attention since the photocatalyst is able to completely mineralize organic carbon to carbon monoxide and water under ambient conditions and using atmospheric oxygen as the oxidant [11].

Titania $\left(\mathrm{TiO}_{2}\right)$ and zinc oxide $(\mathrm{ZnO})$ are widely used in photocatalytic studies. $\mathrm{ZnO}$, is inexpensive and has similar band gap energy $(3.2 \mathrm{eV})$ to $\mathrm{TiO}_{2}[12]$, has attracted much interest as it capable of absorbing a larger fraction of UV spectrum if compared to $\mathrm{TiO}_{2}$ [13]. However, semiconductor photocatalysis suffers from high recombination of charge carrier, which results in low degradation efficiency. Modification of $\mathrm{ZnO}$ via coupling with silver (Ag) has been attempted and enhanced photocatalytic efficiency of the catalyst has been observed. Thus far, Ag/ZnO heterostructures have been synthesized using hydrothermal and solvothermal methods [14-16], electro spinning [17], solgel [18], flame spray pyrolysis [19] and RF magnetron sputtering [20] methods. However, most of these methods are either inefficient, or require expensive instruments. Ag nanoparticles can be produced by the photoreduction of $\mathrm{Ag}^{+}$[21].

In this study, $\mathrm{ZnO}$ and $\mathrm{Ag} / \mathrm{ZnO}$ photocatalysts with different $\mathrm{Ag}$ contents were synthesized using a simple precipitation-irradiation technique and their photocatalytic activities in the degradation of methyl orange dye under UV- irradiation were evaluated.

\section{Materials and Methods}

\subsection{Synthesis of Ag/ZnO nanoparticles}

$\mathrm{Ag} / \mathrm{ZnO}$ synthesized through a precipitation-irradiation process. A solution mixture containing $\mathrm{Zn}\left(\mathrm{NO}_{3}\right)_{2} .6 \mathrm{H}_{2} \mathrm{O}(\mathrm{HmbG})$ and $\mathrm{AgNO}_{3}$ (Bendosen) was titrated with $0.1 \mathrm{M} \mathrm{NaOH}$ solution until pH 10 was reached. The resulting precipitate was filtered and washed with deionized water. The precipitate was then suspended in $1 \mathrm{~L}$ deionized water in a glass photoreactor under continuous stirring (240 $\mathrm{rpm}$ ) and irradiated with 6 watts UV-A light (Hitachi) for $12 \mathrm{~h}$. The product was collected by centrifugation at $4000 \mathrm{rpm}$ for $20 \mathrm{~min}$ and dried overnight at $60-80{ }^{\circ} \mathrm{C}$. A similar procedure was employed to synthesize pure $\mathrm{ZnO}$. The designations for the prepared catalysts are listed in Table 1.

Table 1. Preparative conditions for $\mathrm{ZnO}$ and $\mathrm{Ag} / \mathrm{ZnO}$ photocatalyts and their corresponding physical properties.

\begin{tabular}{|c|c|c|c|c|}
\hline Sample Label & $\begin{array}{c}\mathrm{Zn}\left(\mathrm{NO}_{3}\right)_{2 .} 6 \mathrm{H}_{2} \mathrm{O} \\
(\mathrm{mol})\end{array}$ & $\begin{array}{c}\mathrm{AgNO}_{3} \\
(\mathrm{~mol})\end{array}$ & $\begin{array}{l}\text { Surface area } \\
\qquad\left(\mathrm{m}^{2} \mathrm{~g}^{-1}\right)\end{array}$ & $\begin{array}{c}\text { Band gap } \\
\text { energy }(e V)\end{array}$ \\
\hline $\mathrm{ZnO}$ & \multirow{4}{*}{0.5} & 0 & 13.36 & 3.22 \\
\hline 1-AgZnO & & $5 \times 10^{-4}$ & 13.64 & 3.22 \\
\hline 2-AgZnO & & $10 \times 10^{-4}$ & 7.62 & 3.22 \\
\hline 3-AgZnO & & $15 \times 10^{-4}$ & 10.88 & 3.22 \\
\hline
\end{tabular}




\subsection{Characterization}

The phases of the photocatalysts were analyzed using Shimadzu XRD-6000 diffractometer while morphology was recorded on JEOL JSM-6400 Transmission Electron Microscope. The surface area of the photocatalysts was determined from $\mathrm{N}_{2}$ adsorption isotherm using Belsorp mini II. The band gap energies of the prepared samples were evaluated based on UV-Visible absorption spectra recorded on Perkin Elmer Lambda 750 UV-Vis-NIR Spectrometer.

\subsection{Photocatalytic Studies}

Photocatalytic activities of the synthesized catalysts were evaluated by suspending $0.8 \mathrm{~g}$ of the catalysts in $10 \mathrm{mgL}^{-1}$ methyl orange dye solution (MO, $1 \mathrm{~L}$ ) in a glass photoreactor under 6 watt of UV-A irradiation (Hitachi). The mixture was initially stirred under dark conditions for $30 \mathrm{~min}$. to obtain an adsorption-desorption equilibrium prior to irradiation. During irradiation, agitation was maintained using a magnetic stirrer and air was bubbled into the reaction medium to ensure a constant supply of oxygen. $10 \mathrm{ml}$ of test samples were drawn at specific time intervals during $4 \mathrm{~h}$ of irradiation and immediately filtered with $0.45 \mu \mathrm{m}$ cellulose nitrate filter to remove the catalysts. The MO concentration in the test sample was determined by a Perkin Elmer UV/Vis Lambda 35 Spectrophotometer at $\lambda_{\max }=464 \mathrm{~nm}$. The amount of degraded MO was calculated using the following equation:

$$
\text { Amount of MO degraded }\left(\mathrm{mgg}^{-1}\right)=\frac{\left(\mathrm{C}_{0}-\mathrm{C}_{\mathrm{f}}\right)\left(\mathrm{mgL}^{-1}\right) \times \text { Volume }(\mathrm{L})}{\text { Mass of catalyst }(\mathrm{g})}
$$

Where $\mathrm{C}_{0}$ and $\mathrm{C}_{\mathrm{f}}$ are the initial and final concentrations of $\mathrm{MO}$, respectively.

\section{Results and discussion}

\subsection{Catalyst characterization}

XRD analysis was used to determine the crystallographic structure and evaluate the changes in the phase structure of $\mathrm{Ag} / \mathrm{ZnO}$. The XRD patterns of the synthesized $\mathrm{ZnO}$ and $\mathrm{Ag} / \mathrm{ZnO}$ with different Ag loads are shown in Figure 1. The diffraction peaks corresponding to hexagonal ZnO (01-079-0205) were observed. No diffraction peaks characteristic of $\mathrm{Ag}$ were observed in any of the $\mathrm{Ag} / \mathrm{ZnO}$ catalysts.

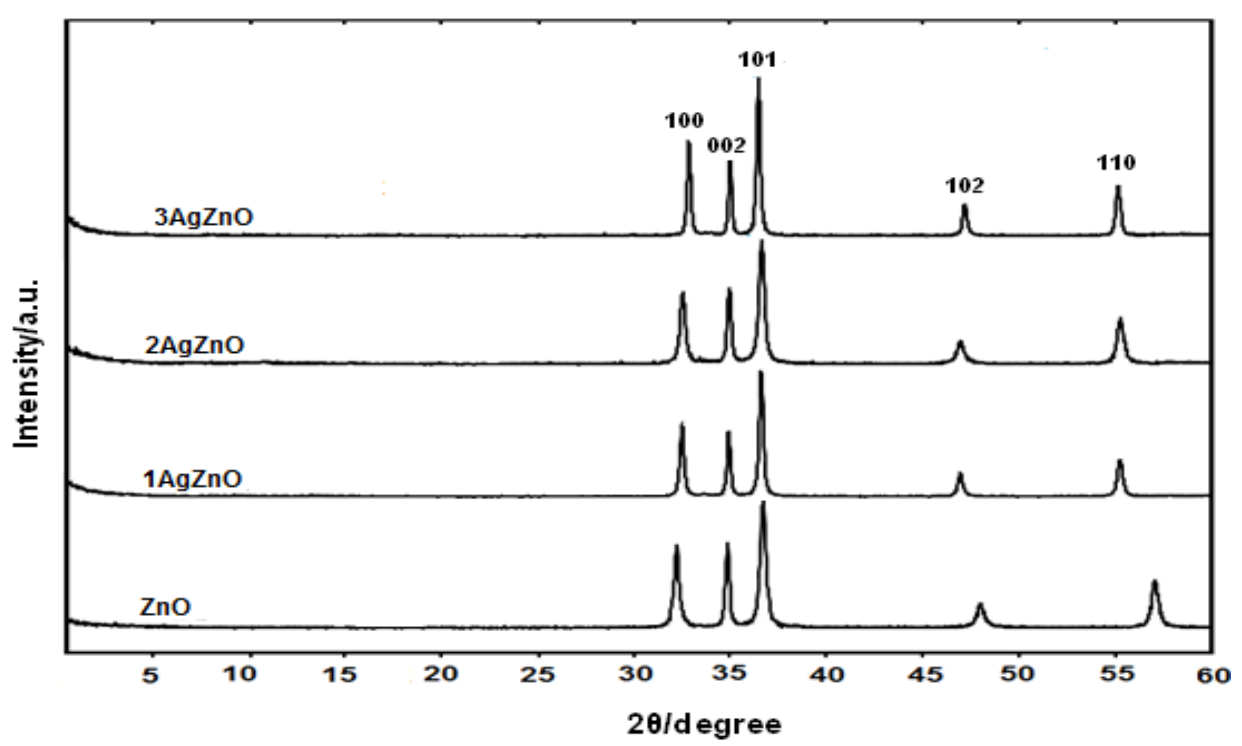

Figure 1. $\mathrm{XRD}$ patterns of $\mathrm{ZnO}$ and $\mathrm{Ag} / \mathrm{ZnO}$ catalysts with different $\mathrm{Ag}$ content. 
The morphologies of $\mathrm{ZnO}$ and $\mathrm{Ag} / \mathrm{ZnO}$ are illustrated in Figure 2. The TEM micrographs showed that the rod shaped $\mathrm{ZnO}$ particles changed to nearly spherical particles upon the addition of Ag. The particles were so highly agglomerated that the average particle size of the photocatalysts could not be determined. There is no significant difference in the surface area of $\mathrm{ZnO}$ and Ag-doped $\mathrm{ZnO}$ (Table 1). A slight decrease in surface area, observed upon the addition of $2 \mathrm{wt} \% \mathrm{Ag}$ onto $\mathrm{ZnO}$, can be attributed to the change in the morphology and particle agglomeration of the sample as observed from the TEM images.
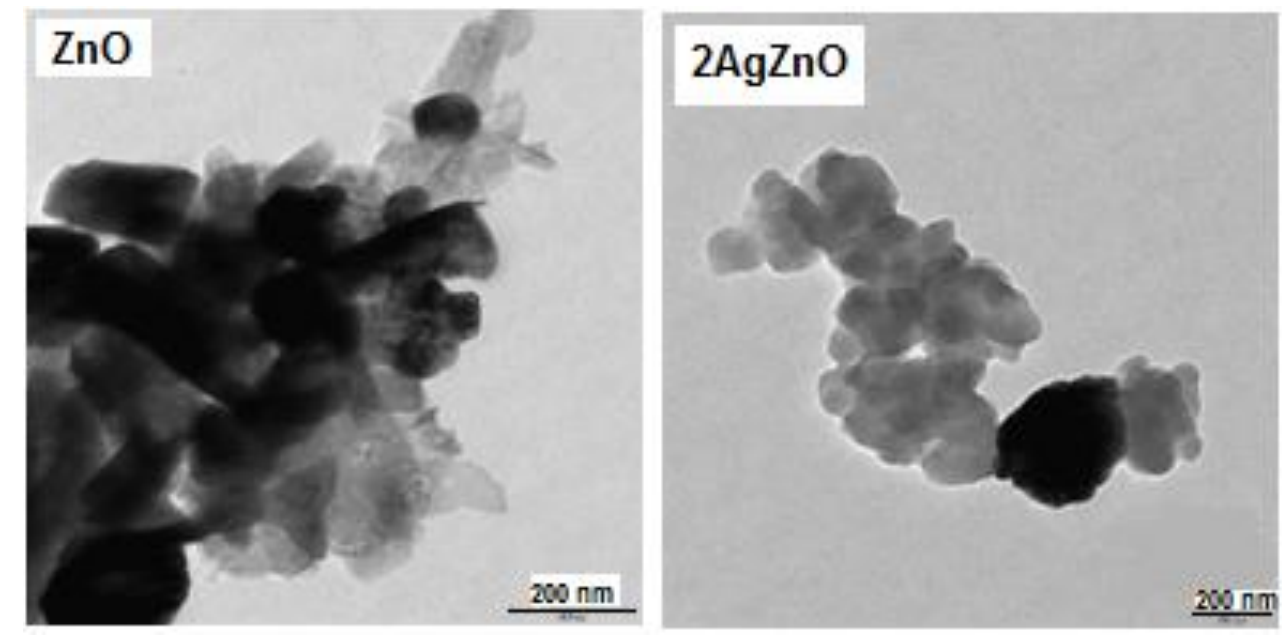

Figure 2. TEM images of the $\mathrm{ZnO}$ and $\mathrm{Ag}$ doped $\mathrm{ZnO}$ photocatalysts.

Figure 3 shows a plot of [(Ahv) $\left.{ }^{2}\right]$ as a function of photon energy, (hv) for the prepared samples. The band gap energy of the samples was estimated from the intercept of the tangent at the $x$-axis of the graph (Table 1). All samples exhibit the same band gap energy indicating similar photoresponsive properties [22].

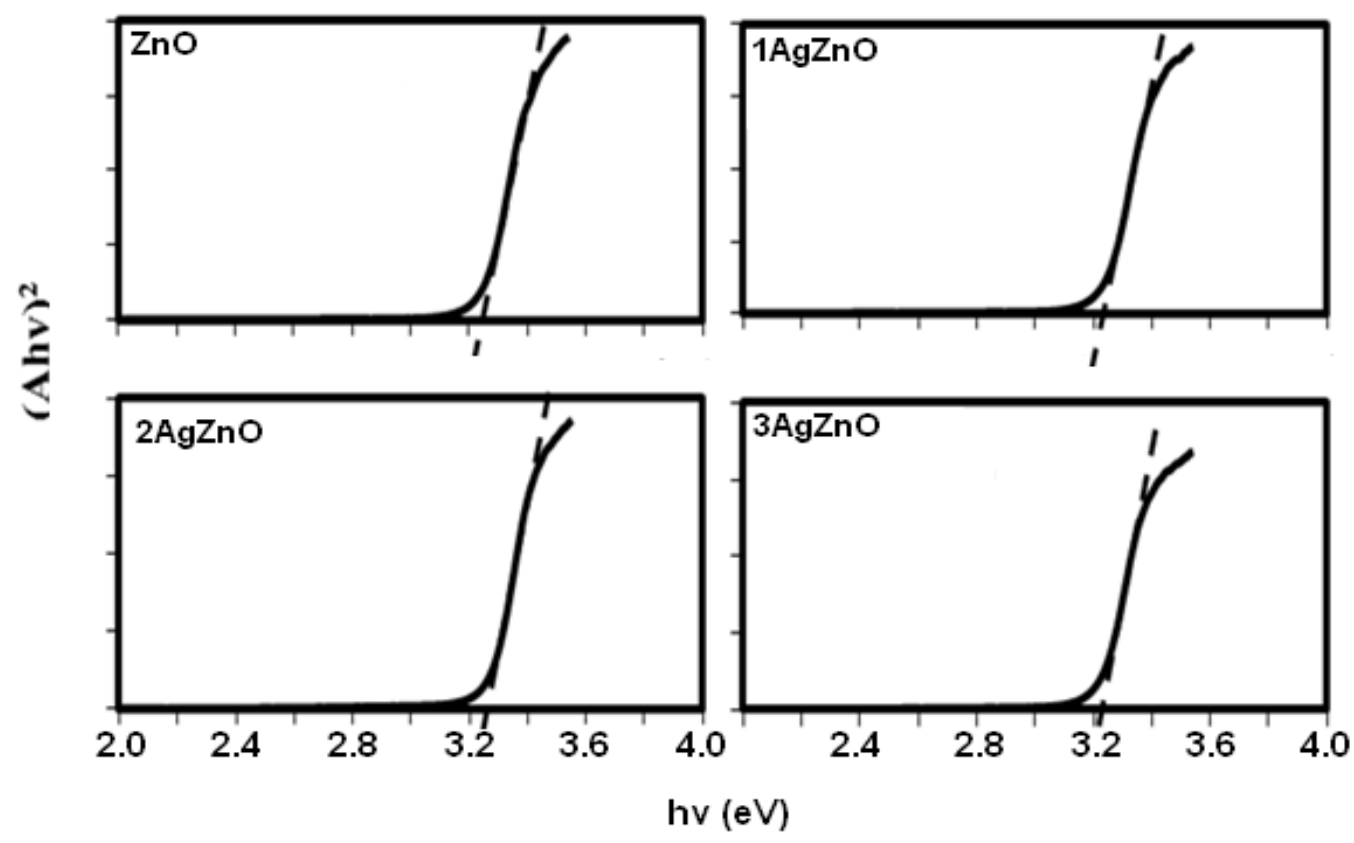

Figure 3. Band gap energy of undoped and Ag-doped $\mathrm{ZnO}$ photocatalysts. 


\subsection{Photocatalytic activity}

Figure 4(a) shows the progressive degradation of $\mathrm{MO}$ dyes as a function of irradiation time by undoped and Ag-doped $\mathrm{ZnO}$ catalysts. The photodegradation of $\mathrm{MO}$ increased with increasing Ag loading up to $2 \%$ but then decreased at higher catalyst amounts. A straight line plot of $\ln \mathrm{C} / \mathrm{C}_{\mathrm{o}} \mathrm{vs}$ time (Figure 4(b)) was obtained indicating that the photodegradation of MO followed the LangmuirHinshelwood pseudo first order kinetics model.
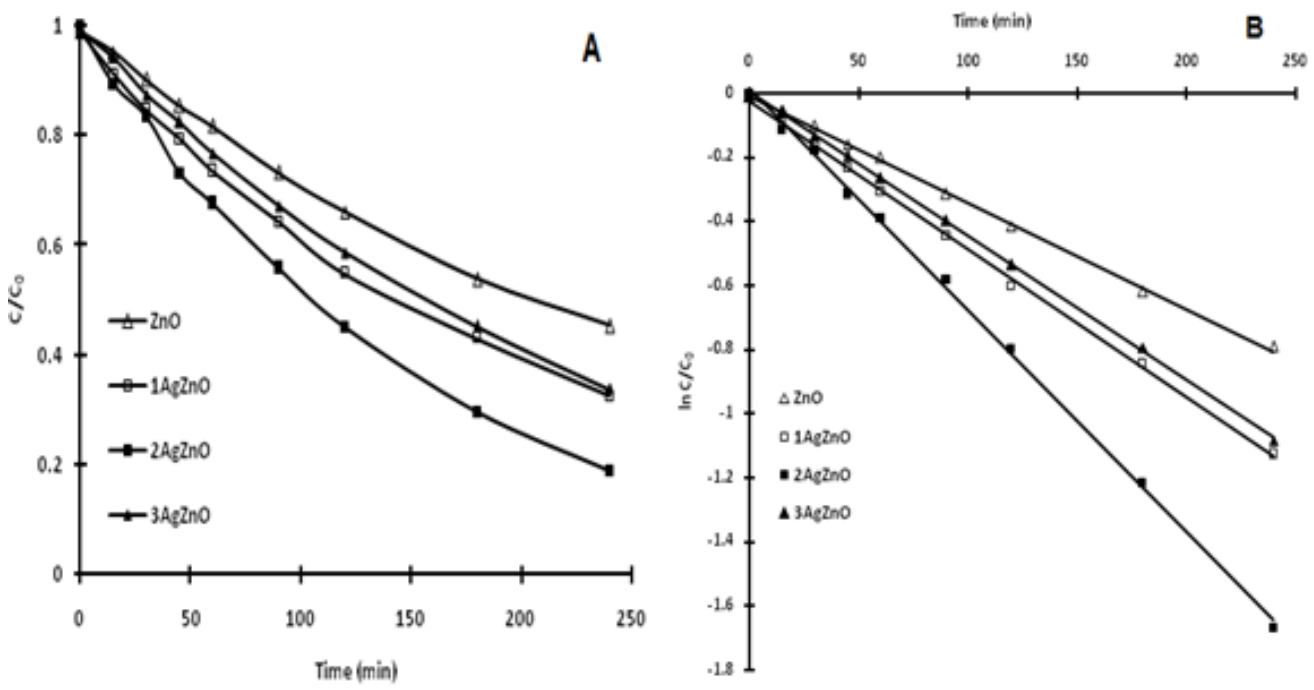

Figure 4. (A) Progressive degradation of Methyl Orange dye and (B) the kinetic analysis of Methyl Orange degradation by $\mathrm{ZnO}$ and Ag-doped $\mathrm{ZnO}$ photocatalysts.

[Conditions: $0.8 \mathrm{~g}$ catalyst, $1 \mathrm{~L}$ of $10 \mathrm{mg} / \mathrm{L}$ Methyl Orange solution]

The amount of MO degraded and the corresponding rate constants are listed in Table 2.

Table 2. Removal percentage of Methyl Orange dye for different amounts of Ag.

\begin{tabular}{|c|c|c|c|}
\hline Photocatalyst & $\begin{array}{c}\text { MO Degraded } \\
\text { (mgg-1) }^{-1}\end{array}$ & $\begin{array}{c}\text { Rate constant, } \\
\text { kobs }\left(\mathbf{x ~ 1 0 - 3} \mathbf{~ m i n}^{-1}\right)\end{array}$ & $\mathbf{R}^{\mathbf{2}}$ \\
\hline Pure ZnO & 6.88 & 3 & 0.998 \\
\hline 1-AgZnO & 8.50 & 4 & 0.999 \\
\hline 2-AgZnO & 10.13 & 7 & 0.998 \\
\hline 3-AgZnO & 8.25 & 4 & 0.999 \\
\hline
\end{tabular}

Photocatalytic activity of $\mathrm{ZnO}$ is enhanced in the presence of Ag. It is well known that when a noble metal is deposited on the surface of n-type semiconductor particles such as $\mathrm{ZnO}$, a Schottky barrier is formed at the interface between the noble metal and the semiconductor [23]. This Schottky barrier can effectively trap photoinduced electrons, inhibit the recombination of photoinduced electrons and holes and subsequently enhance the photocatalytic activity of the catalyst. The photocatalytic performance of $\mathrm{Ag} / \mathrm{ZnO}$ is also affected by the amount of $\mathrm{Ag}$ doped on the $\mathrm{ZnO}$ with $2 \mathrm{wt} \%$ Ag exhibiting the highest photocatalytic activity. This shows that the amount of deposited metal can strongly affect the transfer behavior of photoinduced charge carriers. At a higher Ag loading ( $3 \mathrm{wt} \%)$, the $\mathrm{Ag}$ acts as a recombination center of photoinduced electron and hole pairs leading to a reduction in photocatalytic activity. Therefore, the improved photocatalytic activity observed for $\mathrm{Ag} / \mathrm{ZnO}$ catalysts can be attributed to the ability of Ag to trap the photogenerated 
electrons that improves the separation of electron-hole pairs and the different morphology of the catalysts when compared to that of $\mathrm{ZnO}$.

\subsection{Reusability Test}

The reusability of the 2-AgZnO photocatalyst for the degradation of $\mathrm{MO}$ was conducted with 10 $\mathrm{mg} / \mathrm{L}$ of $\mathrm{MO}$ and $0.8 \mathrm{~g} / \mathrm{L}$ of $2-\mathrm{AgZnO}$. The catalyst particles resulting from the photocatalytic degradation experiments were filtered, washed and dried prior to being employed in the reusability tests on fresh MO solutions. As illustrated in Figure 5, no significant decrease in photocatalytic performance of $\mathrm{MO}$ photodegradation was observed up to 3 cycles indicating the stability and effectiveness of the 2-Ag/ZnO photocatalyst.

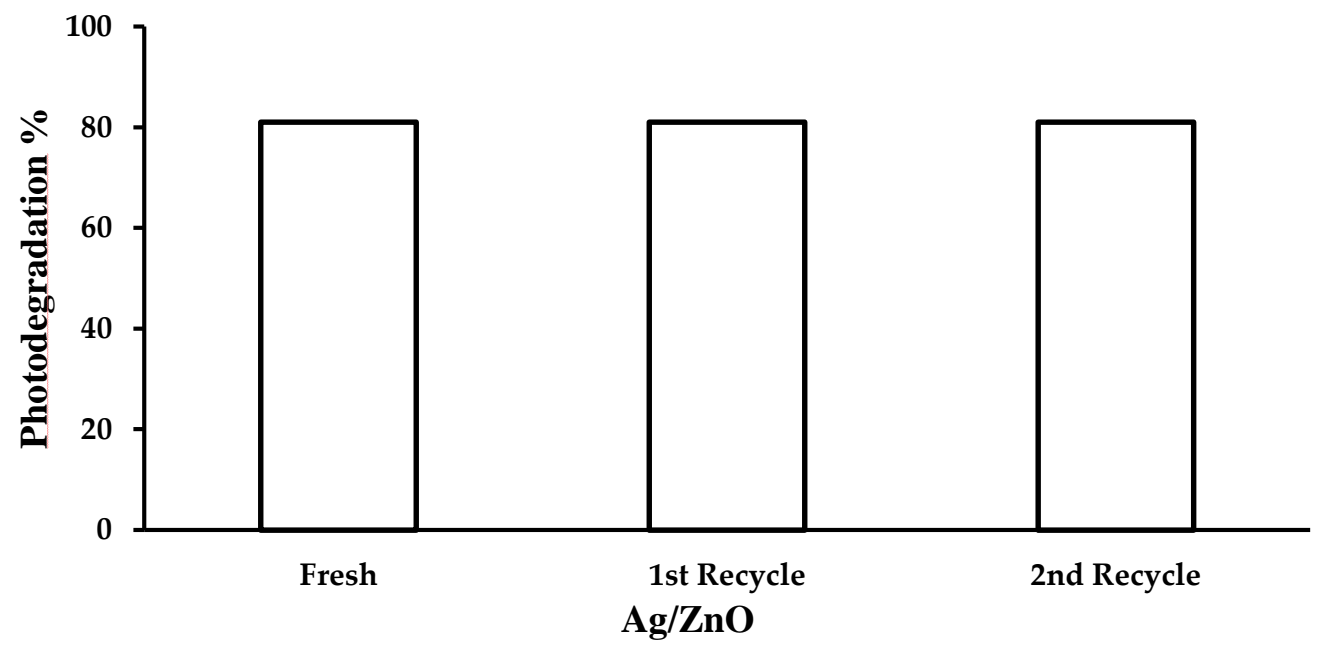

Figure 5. Reusability of 2-AgZnO in the photodegradation of Methyl Orange dye.

\section{Role of $\mathrm{ZnO}-\mathrm{Ag}$ in biomedical application}

To date, the countless potential of $\mathrm{ZnO}$-based nanostructures for biomedical applications has been revealed, due to their unique electronic, optical, catalytical, antimicrobial properties, and also their brilliant biocompatibility. Generally, inorganic antibacterial agents such as metal and metal oxides are advantageous compared to organic compound due to their stability [24, 25]. Among the metal oxides, $\mathrm{ZnO}$ has appealed a special attention as antibacterial agent. In addition, $\mathrm{ZnO}$ nanoparticles (ZnO-NPs) reveal antibacterial activity and can reduce the attachment and viability of microbes on biomedical surfaces $[26,27]$. Moreover, the formation of reaction oxygen species (ROS) and the release of $\mathrm{Zn}{ }^{2+}$ ions from $\mathrm{ZnO}-\mathrm{NPs}$ can lead to serious damage of the bacterial cell membrane [28, 29]. Additionally, as a type of $\mathrm{pH}$-responsive $\mathrm{ZnO}$, it could be used as a drug carrier in $\mathrm{pH}$-responsive systems. However, to our knowledge, there is controversy concerning the nanotoxicity of $\mathrm{ZnO}$ nanostructures toward healthy tissue [30-32]. So far, numerous studies have exposed the antibacterial mechanisms of ZnO-NPs, which involve the generation of ROS, [33, 34] the release of zinc ions from $\mathrm{ZnO}$ and the penetration and disorganization of the bacterial membrane upon contact with specific $\mathrm{ZnO}$ nanostructures, such as nanoneedles and nanorod arrays, [35, 36]. Furthermore, Ag in the form of $\mathrm{Ag}$ nanoparticles the surface area is increased and thereby antimicrobial efficacy is greatly enhanced [37, 38].

\section{Conclusion}

$\mathrm{ZnO}$ and Ag-doped $\mathrm{ZnO}$ catalysts were successfully synthesized via a precipitation-irradiation method. The addition of Ag resulted in morphological changes of $\mathrm{ZnO}$ from rod-like structures to 
nearly spherical particles and a reduction in surface area. Photocatalytic efficiency of synthesized $\mathrm{ZnO}$ catalyst in the photodegradation of $\mathrm{MO}$ is enhanced upon the addition of $\mathrm{Ag}$, and $2 \% \mathrm{AgZnO}$ exhibited the highest photocatalytic activity. The enhancement in the photocatalytic efficiency of $\mathrm{ZnO}$ was due to the improved separation of photo-induced electron-hole pairs.

\section{Acknowledgement}

The authors acknowledge the financial support rendered by the Ministry of Higher Education, Malaysia through the Fundamental Research Grant Scheme (vot no. 5524150) and RU004-2017 Research Grant Project.

\section{References}

[1] Bouasla, C.; Samar, M.E.H.; Ismail, F. Degradation of methyl violet 6B dye by the Fenton process. Desalination. 2010, 254, pp. 35-41. doi: 10.1016/j.desal.2009.12.017

[2] Monteagudo, J.M.; Durán, A.; Martín, I.S.; Aguirre, M. Catalytic degradation of Orange II in a ferrioxalate-assisted photo-Fenton process using a combined UV-A/C-solar pilot-plant system. Appl. Catal. B: Environ. 2010. 95, pp. 120-129. doi: 10.1016/j.apcatb.2009.12.018

[3] Fassi, S.; Djebbar, K.; Bousnoubra, I.; Chenini, H.; Sehili, T. Oxidation of bromocresol green by different advanced oxidation processes: Fenton, fenton-like, photo-fenton, photo-fenton-like and solar light: Comparative Study. Desalin. Water Treat. 2014. 52, pp. 4982-4989. doi: 10.1080/19443994.2013.809971

[4] Guo, X.; Tang, Y.; Wei, Z.; Hou, H.; Yang, X.; Wang, Z. Ozonation of some dyes in aqueous solution and toxicological assessment of their oxidation products. Fresenius Environ. Bull. 2013. 22, pp. 16891696.

[5] Karunya, A.; Rose C.; Valli Nachiar, C. Biodegradation of the textile dye Mordant Black 17 (Calcon) by moreaxella osloensis isolated from textile effluent contaminated site. World J. Microbiol. Biotechnol. 2014. 30, pp. 915-924. doi: 10.1007/s11274-013-1509-8

[6] Prasad, S.S.; Aikat, K.; Study of biodegradation and biodecolourization of azo dye by Enterobacter sp SXCR. Environ. Technol. 2014. 35, pp. 956-965. doi: 10.1080/09593330.2013.856957

[7] Vignesh, K., Rajarajan, M., Suganthi, A. Visible light assisted photocatalytic performance of Ni and $\mathrm{Th}$ codoped $\mathrm{ZnO}$ nanoparticle for the degradation of methylene blue dye. J. Ind. Eng. Chem. 2014, 20, pp. 3826-3833. doi: 10.1016/j.jiec.2013.12.086

[8] Habibi, M.H.; Habibi, A.H.; Photocatalytic degradation of Brilliant Red M5B using four different nanocomposites $\left(\mathrm{ZnFe}_{2} \mathrm{O}_{4}\right.$, porous $\left.\mathrm{ZnFe}_{2} \mathrm{O}_{4}, \mathrm{ZnFe}_{2} \mathrm{O}_{4}-\mathrm{TiO}_{2}, \mathrm{FeTiO}_{3}\right)$ coated on glass. J. Ind. Eng. Chem. 2014. 20, pp. 2964-2968. doi: 10.1016/j.jiec.2013.10.066

[9] Salleh, M.A.M.; Mahmoud, D.K.; Karim, W.A.W.A.; Idris, A. Cationic and anionic dye adsorption on agricultrural solid wastes: A comprehensive review. Desalination. 2011. 280, 1-13. doi: /10.1016/j.desal.2011.07.019

[10] Yagub, M.T.; Sen, T.K.; Afroze, S.; Ang, H.M. Dye and its removal from aqueous solution by adsorption: A review. Adv. Colloid Interface Sci. 2014. 209, pp. 172-184. doi: 10.1016/j.cis.2014.04.002

[11] Chatterjee, D.; Dasgupta, S. Visible light induced photocatalytic degradation of organic pollutants. J. Photochem. Photobio. C: Photochem. Rev. 2005. 6, pp. 186-205. doi: 10.1016/j.jphotochemrev.2005.09.001

[12] Kansal S.K.; Singh, M.; Sud, D. Studies on $\mathrm{TiO}_{2} / \mathrm{ZnO}$ photocatalysed degradation of lignin. J. Hazard. Mater. 2008. 153, pp. 412-417. doi: 10.1016/j.jhazmat.2007.08.091

[13] Behnajady, M.A.; Modirshahla, N.; Hamzavi, R.; Kinetic study on photocatalytic degradation of C.I.Acid Yellow 23 by $\mathrm{ZnO}$ photocatalyst. J. Hazard. Mater. 2006. 133, pp. 226-232. doi: 10.1016/j.jhazmat.2005.10.022. 
[14] Lu, W.; Gao, S.; Wang, J. One-pot synthesis of Ag/ZnO self-assembled 3D hollow microspheres with enhanced photocatalytic performance. J. Phys. Chem. C. 2008. 112, pp. doi: 10.1021/jp803654k [15] Zheng, Y.; Zheng, L.; Zhan, Y.; Lin, X.; Zheng, Q.; Wei, K. Ag/ZnO heterostructure nanocrystals: synthesis, characterization, and photocatalysis. Inorg. Chem. 2007. 46, pp. 6980-6986. doi: 10.1021/ic700688f

[16] Wu, C.; Shen, L.; Cai Zhang, Y.; Huang, Q. Solvothermal synthesis of Ag/ZnO nanocomposite with enhanced photocatalytic activity. Mater. Lett. 2013. 106, pp. 104-106. doi: 10.1016/j.matlet.2013.05.004

[17] Lin, D.; Wu, H.; Zhang, R.; Pan, W. Enhanced photocatalysis of electrospun Ag-ZnO heterostructured nanofibers. Chem. Mat. 2009. 21, pp. 3479-3484. doi: 10.1021/cm900225p

[18] Jang, Y.H.; Kochuveedu, S.T.; Cha, M.A.; Jang, Y.J.; Lee, J.Y.; Lee, J.; Lee, J.; Kim, J.; Ryu, D.Y.; Kim, D.H. Synthesis and photocatalytic properties of hierarchical metal nanoparticles/ZnO thin films hetero nanostructures assisted by diblock copolymer inverse micellar nanotemplates. J. Colloid Interface Sci. 2010. 345, pp. 125-130. doi: 10.1016/j.jcis.2010.01.040

[19] Height, M.J.; Pratsinis, S.E.; Mekasuwandumrong, O.; Praserthdam, P. Ag-ZnO catalysts for UVphotodegradation of methylene blue. Appl. Catal. B: Environ. 2006. 63, pp. 305-312. doi: 10.1016/j.apcatb.2005.10.018

[20] Tan, T.; Li, Y.; Liu, Y.; Wang, B.; Song, X.; Li, E.; Wang, H.; Yan, H. Two-step preparation of $\mathrm{Ag} /$ tetrapod-like $\mathrm{ZnO}$ with photocatalytic activity by thermal evaporation and sputtering. Mater. Chem. Phys. 2008. 111, pp. 305-308. doi: 10.1016/j.matchemphys.2008.04.013

[21] Lee, K. X.; Shameli, K.; Yew, Y. P.; Teow, S-Y.; Jahangirian, H.; Rafiee-Moghaddam, and R.; Webster, T. J. Recent developments in the facile bio-synthesis of gold nanoparticles (AuNPs) and their biomedical applications. Int. J. Nanomedicine 2020; 15, pp. 275-300. doi: 10.2147/IJN.S233789

[22] Lin, C.F.; Wu, C.H.; Onn, Z.N. Degradation of 4-Chlorophenol in $\mathrm{TiO}_{2}$, $\mathrm{WO}_{3}, \mathrm{SnO}_{2}$, $\mathrm{TiO}_{2} / \mathrm{WO}_{3}$ and $\mathrm{TiO}_{2} / \mathrm{SnO}_{2}$ system. J. Hazard. Mater. 2008. 154, pp. 1033-1039. doi: 10.1016/j.jhazmat.2007.11.010

[23] Linsebigler, A.L.; Lu, G.; Yates Jr, J.T. Photocatalysis on $\mathrm{TiO}_{2}$ surfaces: Principles, mechanisms and selected results. Chem. Rev. 1995. 95, pp. 735-758. 10.1021/cr00035a013

[24] Sawai, J. Quantitative evaluation of antibacterial activities of metallic oxide powders ( $\mathrm{ZnO}, \mathrm{MgO}$ and $\mathrm{CaO}$ ) by conductimetric assay. J Microbiol Methods. 2003. 54, pp. 177-182. 10.1016/s01677012(03)00037-x

[25] Balavandy, S. K.; Shameli, K.; Abidin, Z. Z. Rapid and green synthesis of silver nanoparticles via sodium alginate media. Int. J. Electrochem. Sci. 2015.10(1), pp. 486-497.

[26] Brayner, R.; Ferrari-Iliou, R.; Brivois, N.; Djediat, S.; Benedetti, M.F.; Fiévet, F. Toxicological impact studies based on Escherichia coli bacteria in ultrafine $\mathrm{ZnO}$ nanoparticles colloidal medium. Nano Lett. 2006. 6, pp. 866-870. doi: 10.1021/n1052326h

[27] Yamamoto, O.; Influence of particle size on the antibacterial activity of zinc oxide. Int. J. Inorg. Mater. 2001. 3, pp. 643-646. doi: 10.1016/S1466-6049(01)00197-0

[28] Zhang, L., Jiang, Y.; Ding, Y.; Daskalakis, N.; Jeuken, Lars.; Povey, Malcolm.; O'Neill, A.J.; York, D.W. Mechanistic investigation into antibacterial behaviour of suspensions of $\mathrm{ZnO}$ nanoparticles against E. coli. J. Nanopart. Res. 2010. 12, pp. 1625-1636. doi: 10.1007/s11051-009-9711-1

[29] Li, M., Zhu, L.; Lin, D. Toxicity of ZnO nanoparticles to Escherichia coli: mechanism and the influence of medium components. Environ. Sci. Technol. 2011. 45, pp. 1977-1983. doi: 10.1021/es102624t [30] Raghupathi, K.R.; Koodali, R.T.; Manna, A.C. Size-dependent bacterial growth inhibition and mechanism of antibacterial activity of zinc oxide nanoparticles. Langmuir, 2011. 27, pp. 4020-4028. doi: 10.1021/la104825u 
[31] Song, W., Zhang, J.; Guo, J.; Zhang, J.; Ding, F.; Li, L.; Sun, Z. Role of the dissolved zinc ion and reactive oxygen species in cytotoxicity of ZnO nanoparticles. Toxicol Lett. 2010. 199, pp. 389-397. doi: 10.1016/j.toxlet.2010.10.003.

[32] De Berardis, B.; Civitelli, G.; Condello, M.; Lista, P.; Pozzi, R.; Arancia, G.; Meschini, S. Exposure to $\mathrm{ZnO}$ nanoparticles induces oxidative stress and cytotoxicity in human colon carcinoma cells. Toxicol Appl Pharmacol. 2010. 246, pp. 116-127. doi: 10.1016/j.taap.2010.04.012.

[33] Ma, H.; Williams, P.L.; Diamond, S.A. Ecotoxicity of manufactured ZnO nanoparticles-a review. Environ. Pollut. 2013. 172, pp. 6-85. doi: 10.1016/j.envpol.2012.08.011.

[34] Ma, H.; Wallis, L.K.; Diamond, S.; Li, S.; Canas-Carrell, J.; Parra, A. Impact of solar UV radiation on toxicity of $\mathrm{ZnO}$ nanoparticles through photocatalytic reactive oxygen species (ROS) generation and photo-induced dissolution. Environ. Pollut. 2014. 193, pp. 165-172. doi: 10.1016/j.envpol.2014.06.027.

[35] Heinlaan, M., Ivask, A.; Blinova, I.; Dubourguier, H.C.; Kahru, A. Toxicity of nanosized and bulk $\mathrm{ZnO}, \mathrm{CuO}$ and $\mathrm{TiO}_{2}$ to bacteria Vibrio fischeri and crustaceans Daphnia magna and Thamnocephalus platyurus. Chemosphere, 2008. 71, pp. 1308-1316. doi: 10.1016/j.chemosphere.2007.11.047.

[36] Kavitha, T., et al., Glucose sensing, photocatalytic and antibacterial properties of graphene-ZnO nanoparticle hybrids. Carbon, 2012. 50, pp. 2994-3000. doi: 10.1016/j.carbon.2012.02.082

[37] Kim, J.S.; Kuk, E.; Yu, K. N.; Kim J.H, Park, S.J.; Hu, J.L.; Kim, S.H.; Park, Y.K.; Park, Y. H.; Hwang, Shameli, K.; Ahmad, M.; Al-Mulla, E. A. J.; Shabanzadeh, P.; Bagheri, S. Antibacterial effect of silver nanoparticles on talc composites. Res. Chem. Intermed., 2015. 41(1), pp. 251-263. doi: 10.1007/s10534010-9381-6.

[38] Shabanzadeh, P.; Yusof, R.; Shameli, K. Artificial neural network for modeling the size of silver nanoparticles' prepared in montmorillonite/starch bionanocomposites. J. Ind. Eng. Chem. 2015. 24, pp. 42-50. doi: 10.1016/j.jiec.2014.09.007 